Reprod. Nutr. Dévelop., 1980, 20 (6), 1825-1834.

\title{
Dorsal aorta catheterization in rainbow trout (Salmo gairdneri). II. Glucocorticoid levels, hematological data and resumption of feeding for five days after surgery
}

par C. BRY, Y. ZOHAR

Laboratoire de Physiologie des Poissons, I.N.R.A., 78350 Jouy-en-Josas, France.

Summary. Plasma glucocorticoid levels, leucocrit, hematocrit and resumption of feeding were recorded in catheterized rainbow trout for 5 days after cannulation of the dorsal aorta. In some animals, glucocorticoids returned to basal levels, while a regular and active feeding behaviour was resumed shortly after cannulation. In contrast, other individuals demonstrated relatively high and irregular glucocorticoid concentrations and constantly refused food. The leucocrit was significantly depressed from 30 min until $24 \mathrm{~h}$ after cannulation ; after day 1 , this parameter exhibited a recovery profile in all animals, independently of the glucocorticoid levels. During the 5 -day experimental period, seven blood samples were taken, amounting to 10 p. 100 of the total blood volume. In some individuals, the hematocrit continuously declined, suggesting low compensation for the erythrocyte loss. The results of this investigation indicate that well-adapted catheterized trout may be obtained a few days after the operation. Feeding activity should be checked carefully and particular caution used when defermining the volume and frequency of the blood samples.

\section{Introduction.}

The technique of dorsal aorta or heart cannulation allows serial blood sampling from unanesthetized, free-swimming fish (Smith and Bell, 1964 ; Soivio ef al., 1972). This procedure has been used in a number of circulatory, hematological and metabolic studies, mainly on rainbow trout, brook trout and pike (see e.g. Randall ef al., 1965 ; Houston et al., 1971a ; Thorpe and Ince, 1974).

In order to assess some consequences of the handling, anesthetic and surgical procedures involved in the technique and to evaluate the recovery period, various blood parameters such as the hematocrit, hemoglobin content, electrolyte and glucose concentrations have been recorded in cannulated fishes (Houston ef al., 1969 and 1971 b ; Soivio et al., 1972, 1975, 1977). Some indicators (e.g. hematocrit), however, only reflect the immediate and acute effects of anesthetization or surgery. Secondary stress effects (e.g. glucose) may be a help in assessing the condition of the fish a few days after cannulation, but only mean data have been published on this subject (Housfon et al., 1971b) and no particular attention has been given to the individual reactions of the operated fish. In addition, there is no information on the primary stress res- 
ponses, viz. the endocrine patterns consequent to cannulation. As a matter of fact, endocrine patterns and behavioural observations may be sensitive criteria in determining whether the operated fish have returned to an overall « normal » condition, close to the pre-operative state.

From a quantitative standpoint, cortisol is the major adrenocortical steroid hormone in the peripheral plasma of rainbow trout (see review by Idler and Truscott, 1972). It has generally been measured by rather non-specific glucocorticoid assay and used as an indicator of stress in salmonids subjected to various traumatic procedures (Fagerlund, 1967 ; Mazeaud et al., 1977 ; Strange ef al., 1977 ; Strange and Schreck, 1978a and $b$ ). On the other hand, the leucocrit, defined as the volume of packed leucocytes and thrombocytes (expressed as a percentage of the whole blood volume), has been suggested for measuring acute stress in salmonid fish (McLeay and Gordon, 1977).

The implantation of a vascular catheter appeared as a potentially useful technique in our laboratory since we planned to study various endocrine fluctuations or rhythms in adult trout (Zohar, 1980 ; Bry, unpublished data); the demonstration of pulsatile, non-periodical fluctuations, as well as of rhythmic variations when they are not synchronized among individuals, obviously required work on individual, serially sampled animals. Thus, it seemed preferable to sample blood from a catheterized, well-adapted fish (especially in case of frequent sampling) than to use the common procedure which involves handling, anesthetization and vessel puncture. In an attempt to evaluate the stress response induced by handling/surgical procedures and to discriminate between well-adapted and chronically stressed cannulated trout, we studied glucocorticoid and leucocrit patterns until post-cannulation day 5 . We also used feeding activity as a simple indicator of the overall condition of the fish and hematocrit values to examine the effect of repeated blood sampling on erythrocyte balance.

\section{Materials and methods.}

\section{Experimental conditions.}

Between December 1978 and early January 1979, a total of ten 3-year old female rainbow trout (Salmo gairdneri Richardson), originating from a stock kept in concrete raceways at our laboratory, were transferred into individual rectangular tanks containing $100 \mathrm{l}$ of recycling, purified, aerated water with a flow rate of approximately $15 \mathrm{l} / \mathrm{min}$. Six animals (weight range : $1100-1500 \mathrm{~g}$ ) resumed regular feeding after 1 to 12 days and were selected for the experiment.

After a further acclimation period of 10 to 30 days, dorsal aorta catheterization was performed between 9:30 a.m. and 12:30 p.m. on December 1st (female A), January 3rd (females B and C) and February 5th (females D, E and F), as described by Zohar (1980). Seven 0.6-ml blood samples were taken from each animal according to the following schedule : on the day of cannulation $\left(D_{0}\right)$, the fish was quickly netted from the tank and immobilized; blood was withdrawn from the caudal vasculature within $45 \mathrm{sec}$. after initial capture (sample - $10 \mathrm{~min}$ ) in order to obtain the basal levels of the parameters studied. After anesthetization and cannulation about 10 min later, 
a sample was taken via the cannula (sample 0 ). The animal was then returned to its original tank and samples were taken through the cannula on $D_{0}$ at 30 min and $6 \mathrm{~h}$ after cannulation and on post-cannulation days 1,3 and $5\left(D_{1}, D_{3}, D_{5}\right)$ at the same time as the initial capture on $D_{0}$. Feeding activity was evaluated from day 1 (females $A, B, C$ ) or from $6 \mathrm{~h}$ post-cannulation (females $\mathrm{D}, \mathrm{E}, \mathrm{F}$ ), a few minutes after blood sampling. When food was accepted, the usual amount of dry pellets $(0.5-1$ p. 100 of body weight/day) was offered.

All the blood samples were taken with disposable plastic 1-ml syringes previously rinsed with a solution of $200 \mathrm{IU}$ of heparin per $\mathrm{ml}$ of isotonic saline, and distributed into polystyrene fubes set on crushed ice. When the cannula was used, a 0.2- $\mathrm{ml}$ sample, corresponding to the dead volume, was discarded before starting the actual collection.

The fish were maintained in individual tanks on a photoperiod of 9L-15D (8-17). The temperature varied slightly during the 5-day sampling period : $8-10^{\circ} \mathrm{C}$ (female $\mathrm{A}$ ), $5-8{ }^{\circ} \mathrm{C}$ (females B and C), 7-9 ${ }^{\circ} \mathrm{C}$ (females D, E. F). Female $A$ was at the end of the vitellogenesis period; the other 5 animals had ovulated and been stripped of ova at least 3 weeks prior to cannulation.

\section{Determination of hematological parameters.}

Three hematocrit capillaries were filled 5-8 min after blood collection ; they were sealed and immediately centrifuged for $3 \mathrm{~min}$ at $12000 \mathrm{rpm}(15200 \mathrm{~g})$. The hematocrif value for each sampling was the mean of the three deferminations. Within 15 min of centrifugation, the height of the white cell layer, separating the erythrocyles from the plasma, was measured as indicated by McLeay and Gordon (1977) using a microscope with $50 X$ magnification and an ocular micrometer. The leucocrit value, defined as the volume of packed leucocytes and thrombocytes (white layer), expressed as a percentage of the total blood volume, was the mean of the three determinations for each sample.

\section{Glucocorticoid assay.}

Blood was centrifuged for $15 \mathrm{~min}$ at $3500 \mathrm{rpm}$ and the plasma samples stored at $-20^{\circ} \mathrm{C}$. After $3000 \mathrm{dpm}$ of $[1,2,6,7-3 \mathrm{H}]$ cortisol (Amersham, $87 \mathrm{Ci} / \mathrm{mmol}$ ) were added to $100 \mu$ l of plasma as a recovery tracer, extraction was performed with $4 \mathrm{ml}$ of dichloromethane. Each sample was assayed in triplicate for glucocorticoids, using a competitive protein binding assay (CPBA) adapted from Murphy (1967). The fraction of dog serum containing the binding protein was prepared as described by Fèvre (1975).

Separation of the unbound and bound ligands was achieved with a dextrancharcoal suspension. The surpernatant, containing the bound cortisol, was counted with a liquid scintillation spectrometer until 10000 counts had accumulated. After adjustment for recovery, the glucocorticoid vaives were expressed as cortisol equivalents $(\mathrm{ng} / \mathrm{ml})$.

The samples from a given animal were always assayed in the same batch. Intraassay precision, defined as the coefficient of variation (CV) of the glucocorticoid level measured in a sample assayed 5 times in triplicate, was 6 p. $100(X=18 \mathrm{ng} / \mathrm{ml})$ and 4 p. $100(X=45 \mathrm{ng} / \mathrm{ml})$. 
Between-assay variability was 13 p. $100(X=18 \mathrm{ng} / \mathrm{ml}, \mathrm{n}=4)$ and 10 p. 100 $(X=45 \mathrm{ng} / \mathrm{ml}, \mathrm{n}=4)$. The sensitivity of the assay, defined as the cortisol concentration corresponding to a displacement of twice the standard deviation at the zeropoint, was close to $0.05 \mathrm{ng} /$ tube. The assay was used between the limits of 0.1 and $4 \mathrm{ng} / \mathrm{tube}$. This corresponded to a least defectable concentration of $5 \mathrm{ng} / \mathrm{ml}$.

CPBA is frequently criticized for its lack of specificity, and this point must be carefully considered, especially when working with a new species or in a new physiological situation (Slaunwhite, 1973). Six steroids were tested for cross-reactivity, defined as $100 \mathrm{X} / \mathrm{Y}$ where $X$ was the weight of the unlabelled cortisol and $Y$ the weight of the heterologous steroid required to produce $50 \mathrm{p}$. 100 inhibition of ${ }^{3} \mathrm{H}$-cortisol binding. Relative cross reactivity was $48,41,13,10,1,<0.1$ with 11-deoxycortisol, $17 \alpha$-hydroxyprogesterone, cortisone, progesterone, corticosterone and 17 $\alpha$-hydroxy-20 $\beta$ dihydroprogesterone respectively.

In order to assess the true level of interference in our experiment, we compared the values obtained for female $C$ with this assay and with the same assay preceded by a chromatographic step adapted from Sippel et al. (1975). After extraction and evaporation, the dry residue was dissolved in $200 \mu \mathrm{l}$ of dichloromethane-methanol (98:2) and transferred on a small Sephadex LH 20 column $(160 \mathrm{~mm} \times 5 \mathrm{~mm})$. Elution was performed in the same solvent system. 11-deoxycortisol, 17 $\alpha$-hydroxyprogesterone and cortisone were eluted before cortisol. The «cortisol fraction » $(8-11 \mathrm{ml})$ was evaporated, dissolved in $500 \mu \mathrm{l}$ of buffer and assayed as described above.

Statistical analysis. - The differences between the basal and the post-cannulation leucocrit values were determined by the paired tatest.

\section{Results.}

Glucocorticoid levels and resumption of feeding (fig. 1). - Glucocorticoid levels were less than $15 \mathrm{ng} / \mathrm{ml}$ shortly after initial capture and remained unchanged or were moderately elevated (up to $40 \mathrm{ng} / \mathrm{ml}$ ) at the end of anesthetization and cannulation. All fish showed a definite but variable elevation $(35-160 \mathrm{ng} / \mathrm{ml})$ in plasma glucocorticoid concentration at 30 min post-cannulation. Females $B, C, E$ and $F$ resumed regular feeding from 6 to $24 \mathrm{~h}$ after cannulation; in those animals, the glucocorticoids rapidly decreased and stabilized at values close to the initial levels from day 1 or day 3 . On the other hand, females $A$ and $D$ always refused food after catheterization and exhibited higher glucocorticoid levels in comparison to their initial values. In these two fish, the glucocorticoid profiles were irregular, with occasional peaks exceeding the levels observed at $30 \mathrm{~min}$. The catheter remained in position for 5 weeks in female $D$; no food was accepted during this whole period but feeding started again shorlly after the cannula was lost. The comparison between glucocorticoid levels and actual cortisol values obtained after chromatography is shown in fig. 1 for female $C$; in acute stress situations ( 0 and 30-min samples), cortisol was the only substance detected by our glucocorticoid assay on a quantitative basis. On the other hand, in a resting or recovering animal ( $-10 \mathrm{~min}, 6 \mathrm{~h}, \mathrm{D}_{1}, \mathrm{D}_{3}, \mathrm{D}_{5}$ samples), other steroids may make up a considerable ( 50 p. 100 or more) portion of the assayed glucocorticoid level. 


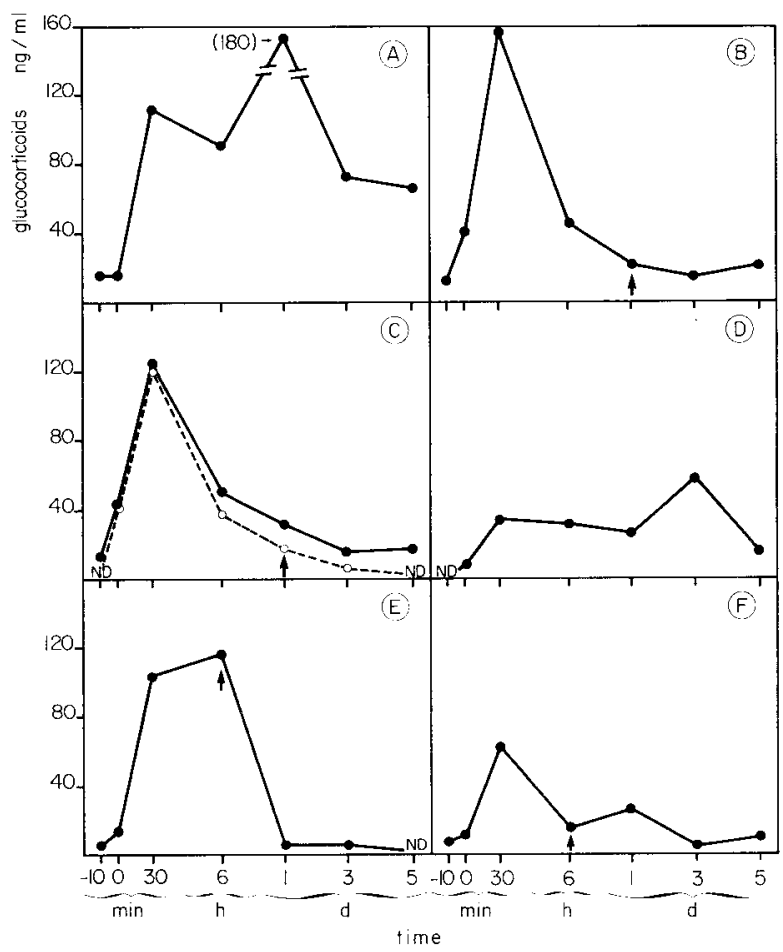

FIG. 1. - Individual plosme profiles of glucocorticoids (-—) or cortisol (0- - - o) in catheterized rainbow trout for 5 days after cannulation of the dorsal aorta. Time 0 indicates the end of cannula implantation. The arrows indicate resumption of feeding activity; ND : not detectable. For further details, see materials and methods.

Leucocrit (fig. 2). - The leucocrit pattern was similar in all 6 animals; it was significantly depressed within 30 min after cannulation and exhibited a further decrease until $24 \mathrm{~h}(\mathrm{P}<0.01)$. The values measured on days 3 and 5 showed an almost complete return to pre-surgery levels.

Hematocrit (fig. 3). - The initial hematocrit values ranged from 23.7 to 33.2 p. 100 (mean 27.5 p. 100). At the end of surgery (sample 0 ), the hematocrit increased markedly in all animals ( +7.4 p. 100 in absolute value on the average). The hematocrit subsequently declined and was close to initial level at $6 \mathrm{~h}$. Two different patterns were then observed : in females A, B, C and D, the hematocrit returned close to its basal value, occasionally after a temporary depression ; females $E$ and $F$ however displayed a continuous decline after the initial upward surge. The mean absoluie difference between the initial and the final (day 5) levels was 1.2 p. 100 in the first group versus 6.5 p. 100 ( 23 p. 100 relative value) in females $E$ and F. On day 13, i.e. 8 days after the completion of the sampling period, the hematocrit value was the same as on day 5 in female $E$, and showed a further 2.5 p. 100 drop from the day 5 value in female $F$. 


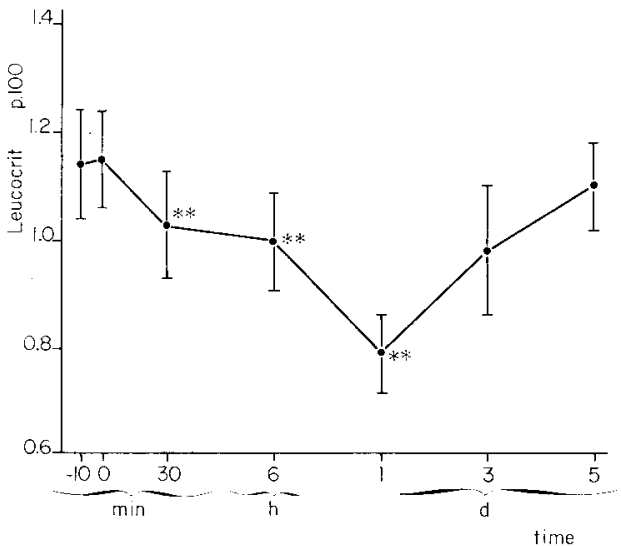

FIG. 2. - Mean leucocrit in catheterized rainbow frout for 5 days after cannulation of the dorsal aoria. Values are expressed as means \pm SEM $(n=6) \ldots *$ indicates statistical difference from initial level $(P<0.01)$

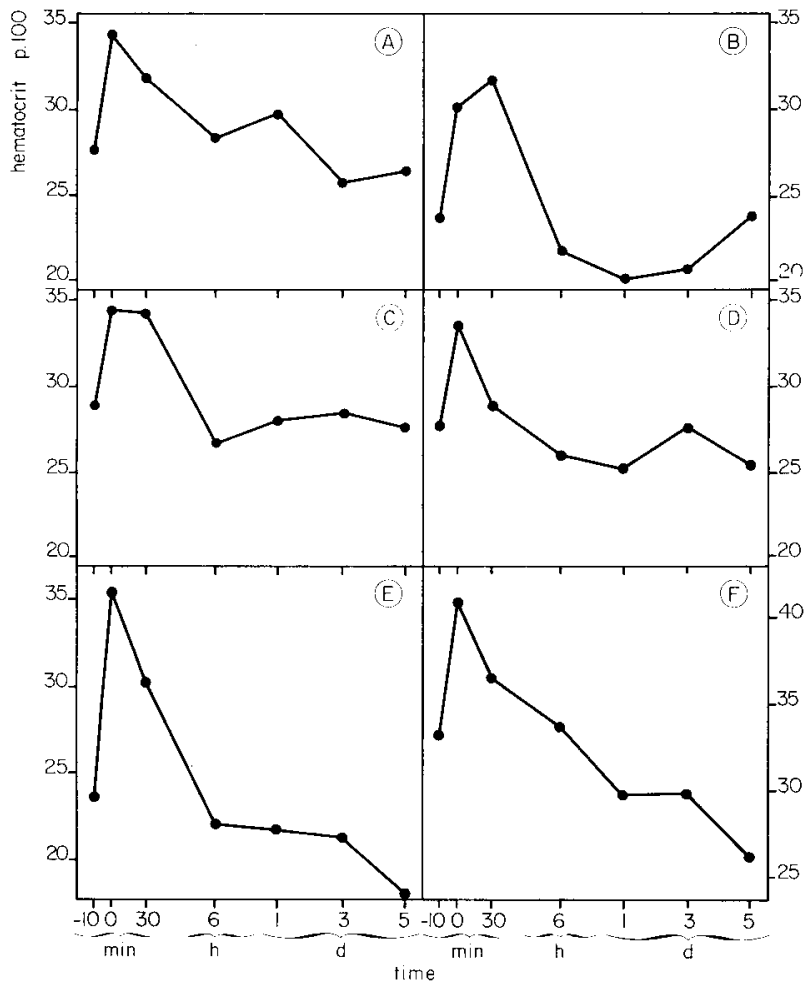

FIG. 3. - Individual variations in hematocrit in catheterized rainbow trout for 5 days after cannulation of the dorsal aorta. For details relative to the amount of blood sampled, see materials and methods. 


\section{Discussion.}

Our study of individual reactions in the chronic presence of the cannula indicates that well-adapted animals may be obtained from about day 3 after the operation. In such fish (females B, C, E and F), the glucocorticoids exhibited a sharp decrease shortly after the peak induced by handling, anesthetization and surgery, and then refurned to basal levels. An active, steady feeding behaviour was resumed concomitantly so that from the stand-point of those two parameters the condition of such animals could be considered as « normal ». In two recent studies (Strange ef al., 1977; Barton, personal communication), no evidence of a diurnal population rhythm in plasma glucocorticoid or cortisol levels was found in juvenile salmonids. These data do not rule out the possibility that a rhythm may be present in sexually mature trout. If a cycle is present, the catheterization technique could be further examined by determining whether the cortisol cycle is continued, modified, or abolished in cannulated trout.

The basal glucocorticoid values $(<15 \mathrm{ng} / \mathrm{ml})$ and the higher levels $(35-160 \mathrm{ng} / \mathrm{ml})$ observed shortly after anesthetization and surgery are consistent with the findings of Strange and Schreck (1978b) in juvenile salmonids at rest or in response to a moderate stress factor. The occasional peaks in the glucocorticoid concentrations recorded late during the post-surgical period (day 1 or 3 ) in animals which did not readily adapt to cannulation ( $A$ and $D$ ), suggest that the continuous presence of the cannula may be responsible for even higher plasma cortisol levels than those observed shortly after the acute surgical phase. This chronic stress may be explained by the disturbance created by the cannula and its float and/or by local irritation at the sites of implantation and fixation.

According to our results, an absolute glucocorticoid value is not always a reliable indicator for the overall condition of the fish ; for example, female $D$ exhibited moderate glucocorticoid levels $(16-35 \mathrm{ng} / \mathrm{ml})$ at $30 \mathrm{~min}, 6 \mathrm{~h}$, day 1 and day 5 after cannulation while constantly refusing food. On the other hand, female $E$ resumed feeding at $6 \mathrm{~h}$ when the glucocorticoids were still at their maximum $(120 \mathrm{ng} / \mathrm{ml})$. However, this latter discrepancy may be only apparent; it might result from the time-lag required for cortisol metabolic clearance and also possibly from some inertia in cortisol secretion after the activation of the pituitary-interrenal axis had ceased at the central nervous system level. Thus, an isolated glucocorticoid value may be of limited interest. In our experimental situation, the pattern of glucocorticoid levels was much more meaningful, since the 4 adapting animals exhibited a clear, rapid decline of glucocorticoids during the $30 \mathrm{~min}-24 \mathrm{~h}$ period, contrary to females A and D.

The comparison between the global glucocorticoid assay and the more specific determination of cortisol (female $C$ ) revealed important differences during the rest and recovery periods. However, both endocrine profiles appeared quite similar and permitted assessment of the phases of acute stress and adaptation, so that a systematic chromatographic step did not seem justified in the present experiment.

The decrease in the number of circulating leucocytes recorded in salmonid fish after exposure to some stressful conditions is a consequence of corticosteroid action (Weinreb, 1958 ; McLeay, 1973) and has been classified as a secondary stress effect (Mazeaud et al., 1977). Although the present study was limited to a few animals, our 
data clearly show that the leucocrit was a sensitive indicator for the acute stress generated by handling and surgery. But it could not be used on a long-term basis to discriminate between well-adapted and distressed fish since a recovery profile, independent of the glucocorticoid levels, was recorded in all individuals.

During $10-\mathrm{min}$ anesthesia on the operating table, the cardioventilatory activity slows down considerably (Houston ef al., 1971a). A severe hypoxia may then develop and induce a shift of plasma to the tissues (Soivio ef al., 1972, 1974, 1976) and erythrocyte swelling (Holeton and Randall, 1967 ; Soivio et al., 1973 ; Casillas and Smith, 1977). These phenomena are most probably responsible for the elevated hematocrit values at 0 and $30 \mathrm{~min}$. Taking into account the small amount of blood (ca $50 \mu \mathrm{l}$ ) usually discarded with the heparinized saline before actual blood collection, a volume of $4.5 \mathrm{ml}$ was withdrawn from each animal in 5 days. According to Conte ef al. (1963) and Huggel et al. (1969), this represents about 10 p. 100 of the total blood volume and was possibly beyond the short-term regulation capabilities of animals $E$ and $F$ since they did not demonstrate any pattern of stable recovery. The deterioration of the hematocrit in these two fish probably reflected a relative trend towards anemia. It should be noted however that the hematocrit on day 5 in female $F$ actually exceeded the initial values exhibited by females $B$ and $E$, and that the situation was not so severe as to disturb feeding activity or induce a glucocorticoid response. Our observations confirm the vulnerability of salmonids to even moderate blood withdrawal, as emphasized by various studies (Smith et al., 1967 ; Soivio et al. 1972, 1975 ; Cairns and Christian, 1978 ; Lane, 1979). No precise timing of the hematocrit pattern at the onset of a struggling/hypoxia situation in salmonids has been published, and we cannot exclude the possibility that the short period (30-45 sec) required for netting and blood sampling (initial sample) might have allowed the hematocrit to increase slightly above the true basal value. In any case, there is a marked trend towards recovery from hemodilution in females $A, B, C$ and $D$, most probably due to the release of erythrocytes from the erythropoietic tissues.

In conclusion, the results of this study indicate the possibility of obtaining welladapted, catheterized trout a few days after the operation. Such individuals appear suitable for experiments involving repeated sampling from minimally stressed fish, provided that the following points are carefully considered : (i) the amount of blood to be sampled should determine the size of the animal selected; (ii) feeding behaviour should be active and regular, as shown in tests run on several successive days after the operation ; (iii) depending on the parameters to be measured, particular caution should be used when determining the sampling frequency, as the handling of the cannula and the sampling procedure itself may disturb the fish to some extent (Soivio et al., 1975 ; Bry, unpublished data).

Reçu en février 1980 Accepté en mai 1980.

Résumé. Le suivi des taux de glucocorticoïdes plasmatiques, du leucocrite, de l'hématocrite, et de l'évolution de la prise alimentaire a été réalisé chez des truites Arc-en-ciel cathétérisées, pendant 5 jours après l'opération. Chez certains animaux, les glucocorticoïdes sont revenus à leurs niveaux de base, tandis que le comportement alimentaire reprenait de façon active et régulière peu de temps après la canulation. Chez d'autres individus 
en revanche, des niveaux de glucocorticoïdes relativement élevés et irréguliers, ainsi qu'un refus constant de toute nourriture ont été observés. Une diminution significative du leucocrite a été mise en évidence depuis 30 min jusqu'à $24 \mathrm{~h}$ après canulation ; après $24 \mathrm{~h}$, ce paramètre a évolué vers un retour à la normale chez tous les animaux, indépendamment des taux de glucocorticoïdes. Au cours des 5 jours de l'expérience, sept prélèvements de sang, soit 10 p. $100 \mathrm{du}$ volume sanguin, ont éfé effectués. L'hématocrite de certains individus a chuté de façon continue, ce qui suggère l'absence d'une compensation suffisante face à la perte d'érythrocytes. Les résultats de ce travail indiquent la possibilité d'obtenir, quelques jours après la cathéterisation, des truiłes bien adaptées. Il est important de surveiller la prise alimentaire et de déterminer avec soin le volume ef la fréquence des prélèvements de sang.

\section{References}

CAIRNS M. A., CHRISTIAN A. R., 1978. Effets of hemorrhagic stress on several blood parameters in adult rainbow trout (Salmo gairdneri) Trans. am. Fish. Soc., 107, 334-340.

CASILLAS E., SMITH L. S., 1977. Effect of stress on blood coagulation and hematology in rainbow trout (Salmo gairdneri). J. Fish Biol., 10, 481-491.

CONTE F. P., WAGNER H. H., HARRIS T. O., 1963. Measurement of blood volume in the fish (Salmo gairdneri) Am. J. Physiol., 205, 533-540.

FAGERLUND U. H. M., 1967. Plasma cortisol concentration in relation to stress in adult sockeye salmon during the freshwater stage of their life cycle. Gen. Comp. Endocrinol., 8, 197-207.

FÈVRE J., 1975. Corticostéroïdes maternels et fœetaux chez la truie en fin de gestation $C$. R. Acad. Sci. Paris, sér. D, 281, 2009-2012.

HOLETON G. F., RANDALL D. J., 1967. The effect of hypoxia upon the partial pressure of gases in the blood and water afferent and efferent to the gills of rainbow trout. J. exp. Biol., 46, 317-327.

HOUSTON A. H., DEWILDE M. A., MADDEN J. A., 1969. Some physiological consequences of aortic catheterization in the brook trout (Salvelinus fontinalis). J. Fish. Res. Bd. Con., 26, 1847-1856.

HOUSTON A. H., MADDEN J. A., WOODS R. J., MILES H. M., 1971a. Some physiological effects of handling and tricaine methanesulphonate anesthetization upon the brook trout. J. Fish. Res. Bd. Con., 28, 625-633.

HOUSTON A. H., MADDEN J. A., WOODS R. J., MILES H. M., 1971b. Variations in the blood and tissue chemistry of brook trout, Salvelinus fontinalis subsequent to handling, anesthesia, and surgery. J. Fish. Res. Bd. Con., 28, 635-642.

HUGGEL H. J., LANE H. C., DUCRET C. G., 1969. Détermination de la courbe d'homogénéisation et du volume sanguin circulant de la truite Salmo gairdneri Rich. par la méthode de la dilution isotopique de l'131/ et du ${ }^{51} \mathrm{Cr}$. J. Physiol. Paris, 61, 145-154.

IDLER D. R., TRUSCOTT B., 1972. Corticosteroids in fish, 126-211. In IDLER D. R., Steroids in nonmammalian verfebrotes, Acad. Press, New York.

LANE H. C., 1979. Some hematological responses of normal and splenectomized rainbow trout, Salmo gairdneri to a 12 p. 100 blood loss. J. Fish Biol., 14, 159-164.

MAZEAUD M. M., MAZEAUD F., DONALDSON E. M., 1977. Primary and secondary effects of stress in fish : some rew data with a general review. Trans. am. Fish. Sac., 106, 201-210.

MCLEAY D. J., 1973. Effects of cortisol and dexamethasone on the pituitary-interrenal axis and abundance of white blood cell types in juvenile coho salmon, Oncorhynchus kisutch. Gen. comp. Endocrinol., 21, 441-450.

MCLEAY D. J., GORDON M. R., 1977. Leucocrit : a simple hematological technique for measuring acute stress in salmonid fish, including stressful concentrations of pulpmill effluent. J. Fish. Res. Bd. Can., 34, 2164-2175.

MURPHY B. E. P., 1967. Some studies of the protein-binding of steroids and their application to the routine micro and ultramicro measurement of various steroids in body fluids by competitive protein-binding radioassay. J. clin. Endocr., 27, 973-990.

RANDALL D. J., SMITH L. S., BRETT J. R., 1965. Dorsal aortic blood pressures recorded from the rainbow trout (Salmo gairdneri). Can. J. Zool., 43, 863-872. 
SIPPEL W. G., LEHMANN P., HOLLMANN G., 1975. Aufomation of multiple sephadex LH-20 column chromatography for the simultaneous separation of plasma corticosteroids. J. Chromatog., 108, 305-312,

SLAUNWHITE W. R. Jr., 1973. Corticosteroid analysis by competitive protein binding, 419-435. In HEFTMANN E., Modern methods of steroid analysis, Acad. Press, New York and London.

SMITH L. S., BELL G. R., 1964. A technique for prolonged blood sampling in free-swimming salmon. J. Fish. Res. Bd. Can., 21, 711-717.

SMITH L. S., BRETT J. R., DAVIS J. C., 1967. Cardiovascular dynamics in swimming adult sockeye salmon. J. Fish. Res. Bd. Can., 24, 1775-1790.

SOIVIO A., WESTMAN K., NYHOLM K., 1972. Improved method of dorsal aorta catheterization : hematological effects followed for three weeks in rainbow trout (Salmo gairdneri). Finn. Fish. Res., 1, 11-21.

SOIVIO A., NYHOLM K., WESTMAN K., 1973. Notes on hematocrit determination on rainbow trout, Salmo gairdneri. Aquaculture, 2, 31-35.

SOIVIO A., MALKONEN M., TUURALA O., 1974. Effects of asphyxia and MS-222 anesthesia on the circulation of the kidney in Salmo gairdneri Richardson. A microscopical study. Ann. Zool. Fennici, 11, 271-275.

SOIVIO A., NYHOLM K., WESTMAN K., 1975. A technique for repeated sampling of the blood of individual resting fish. J. exp. Biol., 62, 207-217.

SOIVIO A., OIKARI A., 1976. Hematological effects of stress on a feleost Esox lucius L. J. Fish Biol., 8, $397-411$.

SOIVIO A., NYHOLM K., HUHTI M., 1977. Effects of anesthesia with MS 222, neutralized MS 222 and benzocaine on the blood constituents of rainbow trout, Salmo gairdneri. J. Fish Biol., 10, 91-101.

STRANGE R. J., SCHRECK C. B., GOLDEN J. J., 1977. Corticoid stress response to handling and temperature in salmonids. Trans. am. Fish. Soc., 106, 213-218.

STRANGE R. J., SCHRECK C. B., 1978a. Anesthetic and handling stress on survival and cortisol concentration in yearling chinook salmon (Oncorhynchus tshawytscha). J. Fish. Res. Bd. Can., 35, 346-349.

STRANGE R. J., SCHRECK C. B., 1978b. Cortisol concentrations in confined juvenile chinook salmon (Oncorhynchus tshawytscha). Trans. am. Fish. Soc., 107, 812-819.

THORPE A., INCE B. W., 1974. The effects of pancreatic hormones, catecholamines, and glucose loading on blood metabolites in the northern pike (Esox lucius L.). Gen. comp. Endocrinol., 23, 29-44.

WEINREB E. L., 1958. Studies on the histology and histopathology of the rainbow trout, Salmo gairdneri irideus. Zoologica, 43, 145-153.

ZOHAR Y., 1980. Dorsal aorta catheterization in rainbow trout (Salmo gairdneri). I. Its validity in the study of blood gonadotropin patterns. Reprod. Nutr. Develop., 20,1811-1823. 